\title{
PENGARUH PEMBERIAN SEDIAAN EMULGEL KITOSAN - EKSTRAK DAUN SIRIH MERAH (PIPER CROCATUM RUIZ \& PAV) DAN EMULGEL KITOSAN-EKSTRAK DAUN BINAHONG (ANREDERA CORDIFOLIA (TEN.) STEENIS) UNTUK PENYEMBUHAN LUKA BAKAR PADA KELINCI
}

\author{
Fakhruddin ${ }^{1}$ Yantri Retno Pertiwi ${ }^{2}$ Rani Purniawati ${ }^{3}$ \\ ${ }^{123}$ STIKes Borneo Cendekia Medika Pangkalan Bun \\ ${ }^{1}$ email : dedekfakhruddin.com, ${ }^{2}$ email : yantriretnopertiwi@gmail.com, ${ }^{3}$ email : \\ ranipurniawati07@gmail.com
}

\begin{abstract}
ABSTRAK
Kulit merupakan bagian terluar tubuh yang digunakan sebagai indikator kesehatan. Luka bakar adalah kerusakan atau kehilangan jaringan tubuh yang disebabkan oleh kontak langsung dengan suhu tinggi seperti api, air panas, listrik, bahan kimia. Luka bakar dapat menyebabkan infeksi. Daun Sirih Merah (Piper crocatum Ruiz \& Pav) dan Daun Binahong (Anredera cordifolia (Ten.) Steenis) merupakan tanaman yang berkhasiat sebagai antiseptik yang digunakan untuk penyembuhan luka bakar. Penelitian ini bertujuan untuk mendapatkan formulasi sediaan emulgel-kitosan ekstrak daun sirih merah dan emulgel-kitosan ekstrak daun binahong yang efektif terhadap penyembuhan luka bakar. Penelitian ini menggunakan rancangan true eksperimental dengan desain pre-post test control grup. Hewan uji yang digunakan kelinci yang berusia \pm 6 bulan. Setiap kelinci mendapatkan 4 perlakuan yaitu kontrol $(+)$, kontrol (-), formulasi I ekstrak daun sirih merah (3\%), formulasi II ekstrak daun sirih merah (6\%), formulasi I ekstrak daun binahong (10\%) dan formulasi II ekstrak daun binahong (20\%). Perlakuan terhadap hewan uji selama 21 hari. Hasil persentase penyembuhan luka bakar diuji dengan uji statistik. Berdasarkan penelitian ini disimpulkan bahwa emulgel kitosan-ekstrak daun sirih merah (Piper crocatum Ruiz \& Pav) dan emulgel-kitosan ekstrak daun binahong (Anredera cordifolia (Ten.) Steenis) terbukti efektif terhadap penyembuhan luka bakar dengan konsentrasi $6 \%$ dan $20 \%$.

Kata kunci: Daun Sirih Merah (Piper Crocatum Ruiz \& Pav), Daun Binahong (Anredera Cordifolia (Ten.) Steenis), Emulgel, Luka Bakar, Kitosan

\section{THE INFLUENCE GIVING OF EMULGEL CHITOSAN - BETEL LEAF EXTRACT RED (PIPER CROCATUM RUIZ \& PAV) AND EMULGEL CHITOSAN - BINAHONG EXTRACT LEAVES (ANREDERA CORDIFOLIA (TEN.) STEENIS) FOR HEALING BURNS IN RABBITS}

\begin{abstract}
The skin is the outer portion of the body that is used as an indicator of health. Burns are damage or loss of body tissue caused by direct contact with high temperatures such as fire, hot water, electricity, chemicals. Burns can cause infection. Red Betel Leaf (Piper crocatum Ruiz \& Pav) and Binahong Leaf (Anredera cordifolia (Ten.) Steenis) are effective antiseptic plants used for healing burns. This study aims to
\end{abstract}


obtain a formulation of emulgel-chitosan, red betel leaf extract and emulgelchitosan, binahong leaf extract which are effective in healing burns. This study uses a true experimental design with a pre-post test control group design. Test animals used rabbits aged \pm 6 months. Each rabbit received 4 treatments namely control (+), control (-), formulation I of red betel leaf extract (3\%), formulation II of red betel leaf extract (6\%), formulation I of binahong leaf extract (10\%) and formulation II Binahong leaf extract (20\%). Treatment of test animals for 21 days. The percentage of burn wound healing results was tested with statistical tests. Based on this study it was concluded that the red betel leaf chitosan (Piper crocatum Ruiz \& Pav) emulgel and the binahong leaf extract (Anredera cordifolia (Ten.) Steenis) proved effective against healing burns with concentrations of $6 \%$ and $20 \%$

Keywords: Red Betel Leaf (Piper Crocatum Ruiz \& Pav), Binahong Leaf (Anredera Cordifolia (Ten.) Steenis), Emulgel, Burns, Chitosan

\section{PENDAHULUAN}

World Health Organization (WHO, 2005 , 1) menyatakan bahwa kesehatan adalah suatu keadaan sehat yang utuh secara fisik, mental, dan sosial manusia. Aspek kesehatan adalah kesehatan fisik. Kesehatan fisik terwujud apabila tidak merasa dan mengeluh sakit pada organ. Kulit merupakan salah satu indikator kesehatan karena kulit adalah organ tubuh yang terletak paling luar yang berfungsi sebagai indra peraba, pelindung terhadap cedera, pelindung tubuh dari kehilangan cairan dan sebagai pengatur suhu tubuh. Keadaan tidak normal fungsi kulit disebabkan oleh infeksi bakteri, jamur, parasit, alergi dan akibat kecelakaan seperti luka bakar.

Salah satu cara penanganan luka bakar yaitu mengobati dengan menggunakan sediaan topical (Inriani, 2012, 2). Pemberian sediaan topical yang tepat dan efektif diharapkan dapat mengurangi dan mencegah infeksi pada luka (Rismana E, 2013, 3). Bentuk sediaan topical yang dapat dengan mudah digunakan untuk pengobatan pada luka bakar salah satunya adalah sediaan gel. Sediaan gel merupakan sediaan yang memiliki daya sebar yang baik diantara sediaan topikal lainnya sehingga lebih mudah untuk dioleskan pada luka.

Selain itu sediaan gel memiliki komponen penyusun yang sebagian besarnya adalah air, sehingga memudahkan pelepasan zat aktif dari sediaan gel ke dalam luka sehingga dapat membantu mempercepat penyembuhan luka. Tanaman sirih merah (Piper crocatum Ruiz \& Pav) merupakan salah satu tanaman obat yang daunnya telah lama dikenal mempunyai khasiat obat untuk menyembuhkan berbagai penyakit, secara turun temurun telah digunakan dan dapat menyembuhkan berbagai jenis penyakit, salah satunya yaitu digunakan untuk mengobati luka. Daun sirih merah mengandung senyawa aktif seperti minyak atsiri, alkaloid, saponin, tanin, dan flavonoid

(Indri W, 2008, 4). Dengan adanya saponin memacu pembentukan kolagen yang berperan dalam proses penyembuhan luka (Abdassah, 2009, 5). Selain itu kandungan minyak atsiri yang terdapat dalam sirih merah mempunyai aktivitas antibakteri yang dapat membantu mencegah terjadinya infeksi 
pada luka bakar dan kandungan flavonoidnya

juga efektif sebagai antiinflamasi. Hal ini didukung dengan penelitian yang telah dilakukan bahwa minyak atsiri daun sirih merah memiliki KHM terhadap bakteri gram positif Bacillus cereus, Staphylococcus aureus dan Staphylococcus epidermidis secara berurutan 1\%, 0,25\% dan 0,5\% (Soerya Dewi, 2013, 6). Serta penelitian ekstrak daun sirih merah memberikan aktivitas antiinflamasi paling baik dengan dosis $50 \mathrm{mg} / \mathrm{kgBB}$ yang mampu menurunkan radang sebesar 85,61\% (Atik, 2011, 7). Karena adanya senyawa kimia yang dapat berkhasiat sebagai antiinflamasi dan antibakteri maka ada kemungkinan daun sirih merah juga dapat berkhasiat sebagai obat untuk luka bakar.

Indonesia akan bahan alam terutama tanaman yang berpotensi besar untuk dimanfaatkan dan dikembangkan secara maksimal (Paju dkk., 2013, 8). Prakash $(2005,9)$, menyatakan bahwa tanaman obat banyak dimanfaatkan sebagai bahan dasar pembuatan obat karena efisien, murah, dan mudah didapat. WHO $(2005,1)$ dan Paju dkk. $(2013,8)$ menegaskan bahwa tanaman yang berkhasiat dan dimanfaatkan sebagai obat dikenal dengan nama obat herbal atau herbal medicine, yang didefinisikan sebagai bahan baku atau sediaan yang berasal dari tanaman yang memiliki efek terapi atau efek lain yang bermanfaat bagi kesehatan manusia. Lebih lanjut dikatakannya bahwa komposisi obat herbal dapat berupa bahan mentah atau bahan yang telah mengalami proses lebih lanjut yang berasal dari satu jenis tanaman atau lebih. Salah satu tanaman yang memiliki banyak khasiat dalam mengobati penyakit adalah tanaman binahong (Anredera cordifolia).
Menurut Rochani (2007, 10), daun binahong memiliki senyawa aktif alkaloid, saponin, dan flavonoid. Manoi (2009, 11), menyatakan bahwa semua bagian dari tanaman binahong ini dapat dimanfaatkan sebagai obat, mulai dari batang, akar, bunga, dan daun. Namun, yang paling sering dimanfaatkan untuk kesehatan sebagai obat herbal adalah daunnya. Shabella (2012, 12), menyatakan bahwa di kalangan masyarakat daun binahong dimanfaatkan untuk mengobati rasa nyeri, maag, sariawan, memberi stamina ekstra, melancarkan peredaran darah, dan asam urat. Selain itu mengkonsumsi binahong juga dapat mengatasi pembengkakan dan pembekuan darah, mengobati diabetes mellitus, menurunkan kolesterol, dan menyembuhkan luka.

Menurut Suseno (2013, 13), tanaman binahong merupakan tanaman obat dari daratan Tiongkok yang dikenal dengan nama asli dheng san chi, sedangkan di dunia internasional binahong dikenal dengan nama hearthleaf madeiravine, di Indonesia tanaman ini dikenal sebagai gondola (Bali), kandula (Madura), uci-uci (Jawa) dan sering digunakan sebagai gapura yang melingkar diatas jalan taman. Prakash (2001, 14), menambahkan bahwa tanaman binahong ini termasuk dalam famili basellaceae yang merupakan salah satu tanaman obat potensial untuk dikembangkan.

Luka adalah rusaknya kesatuan atau komponen jaringan, yang menyebabkan secara spesifik terdapat substansi jaringan yang rusak atau hilang. Ketika luka timbul, beberapa efek akan muncul seperti hilangnya seluruh atau sebagian fungsi organ, respon stress simpatis, perdarahan dan pembekuan darah, kontaminasi bakteri, 
dan kematian sel (Kozier, 1995, 15). Luka pada kulit akan mengalami proses penyembuhan dimulai dari fase inflamasi, fase proliferasi dan fase maturasi (fase epithelisasidan remodelling) (Robert dan Evans, 2004, 16).

Luka yang tidak dirawat dapat menyebabkan komplikasi seperti infeksi dan pendarahan, oleh karenanya luka tidak dapat dibiarkan sembuh sendiri, diperlukan suatu perawatan untuk memperbaiki kerusakan yang terjadi (Syarfati dkk., 2011, 17).

Tujuan dari penelitian ini untuk menguji efektivitas sediaan emulgel kitosan-ekstrak daun sirih merah (Piper crocatum Ruiz \& Pav) dan daun Binahong (Anredera cordifolia (Ten.) Steenis) terhadap penyembuhan luka bakar pada kelinci.

\section{METODE PENELITIAN}

Penelitian tentang pengaruh pemberian sediaan emulgel kitosan-ekstrak daun sirih merah (Piper Crocatum Ruiz \& Pav) dan daun binahong (Anredera Cordifolia (Ten.) Steenis) terhadap penyembuhan luka bakar merupakan penelitian true experimental laboratories dengan rancangan pretestposttest control group design.

\section{Alat dan Bahan Penelitian}

Alat Penelitian. Timbangan digital (Mettler toledo), ayakan mesh 100 (Retsch), alat gelas, wadah gel, kandang hewan, kompor listrik (Maspion), pencukur bulu (Gillette), jangka sorong (Sellery), mikser (Phlips), blender (Phlips), alat uji daya lekat, alat uji daya sebar, lempeng logam $3 \mathrm{~cm}$, kertas saring, waterbath (Memmert).

Bahan Penelitian. Bahan Uji yaitu Simplisia daun sirih merah, simplisia daun binahong (Anredera Cordifolia (Ten.) Steenis), kitosan (PT.Biokitosan), bioplacenton gel (Kalbe Farma), Bahan Habis Pakai yaitu Etanol 70\% (Brataco), Propilenglikol (Brataco), Aquadest (Brataco), tween 80 (Brataco), span 80 (Brataco), VCO, dragendrop, HCL, serbuk mg, karbomer (Brataco) dan kelinci sebagai hewan uji.

Pembuatan Simplisia Daun Sirih Merah dan daun binahong (Anredera cordifolia (Ten.) Steenis)

Daun sirih merah (Piper Crocatum Ruiz \& Pav) dan daun binahong (Anredera cordifolia (Ten.) Steenis) yang diambil adalah daun yang segar, tidak cacat dan dipetik secara manual kemudian daun yang sudah dipanen dicuci dan ditiriskan setelah itu daun dirajang dan dijemur dengan cara diangin-anginkan kemudian daun yang sudah kering dihaluskan dengan cara diblender hingga diperoleh serbuk simplisia kering.

\section{Pembuatan Ekstrak Daun Sirih Merah dan daun binahong}

Serbuk daun sirih merah dan daun binahong kemudian diekstrasi dengan metode maserasi. Menggunakan 2 liter pelarut etanol selama 5 hari, terlindung dari cahaya sambil diaduk sekali-kali setiap hari lalu diperas dan ampasnya dimaserasi kembali dengan cairan penyari. Penyarian diakhiri setelah pelarut tidak berwarna lagi, lalu dipindahkan ke dalam bejana tertutup, dibiarkan pada tempat yang tidak bercahaya, setelah dua hari lalu endapan dipisahkan. Hasil dari 
maserasi daun sirih merah ditimbang kemudian diuapkan dengan menggunakan water bath hingga cairan menjadi pekat.

\section{Skrining Fitokimia}

Skrining fitokimia dilakukan dengan mengidentifikasi kandungan flavonoid, saponin, tanin, alkaloid dan polifenol.

\section{Formula Sediaan Emulgel Kitosan Ekstrak Daun Sirih Merah dan Formula Sediaan Emulgel Kitosan- Ekstrak Daun Binahong.}

Tahap pembuatan formulasi sediaan emulgel kitosan-ekstrak daun sirih merah dan emulgel kitosan-ekstrak daun binahong :

1. Pembuatan gelling agent kitosan Pembuatan gelling agent kitosan adalah kitosan dilarutkan pada asam asetat $1 \%$ kemudian diuapkan dengan water bath hingga terlarut.

2. Pembuatan formulasi emulgel kitosan-ekstrak daun sirih merah dan emulgel kitosan-ekstrak daun binahong

Pembuatan formulasi emulgel ekstrak daun sirih merah dan emulgel ekstrak daun binahong adalah dengan menambahkan gelling agent yang telah dibuat kemudian dicampur dengan zat aktif dan digerus hingga homogen.

Tabel 1 Formulasi sediaan emulgel kitosan-ekstrak daun sirih merah.

\begin{tabular}{llll}
\hline \multirow{1}{*}{ Nama bahan } & \multicolumn{3}{c}{$\begin{array}{c}\text { Formulasi dan komposisi } \\
(\%) \mathrm{b} / \mathrm{v}\end{array}$} \\
\cline { 2 - 4 } & Plasebo & $\mathrm{F} 1$ & $\mathrm{~F} 2$ \\
\hline $\begin{array}{l}\text { Ekstrak daun } \\
\text { sirih merah }\end{array}$ & - & 3 & 6 \\
\hline VCO & 5 & 5 & 5 \\
\hline $\begin{array}{l}\text { Surfaktan 3\% } \\
\begin{array}{l}\text { Tween 80 } \\
\text { Span 80 }\end{array}\end{array}$ & 0,616 & 0,616 & 0,616 \\
\hline Propilenglikol & 5 & 5 & 5 \\
\hline $\begin{array}{l}\text { Add gelling } \\
\text { agent }\end{array}$ & 100 & 100 & 100 \\
\hline
\end{tabular}

(kitosan,

karbopol)

Tabel 2 Formulasi Sediaan Emulgel

Kitosan-Ekstrak Daun Binahong

\begin{tabular}{cccc}
\hline Bahan & \multicolumn{3}{c}{ Formulasi dan komposisi } \\
& \multicolumn{3}{c}{$(\% \mathrm{~b} / \mathrm{v})$} \\
\cline { 2 - 4 } & Plasebo & $\begin{array}{c}\text { Formulasi } \\
1\end{array}$ & $\begin{array}{c}\text { Formulasi } \\
2\end{array}$ \\
\hline $\begin{array}{c}\text { Ekstrak Daun } \\
\text { Binahong }\end{array}$ & - & $10 \%$ & $20 \%$ \\
\hline $\begin{array}{c}\text { Virgin Coconut } \\
\text { Oil (VCO) }\end{array}$ & $5 \%$ & $5 \%$ & $5 \%$ \\
\hline Propilenglikol & $5 \%$ & $5 \%$ & $5 \%$ \\
\hline Tween 80 & $0,616 \%$ & $0,616 \%$ & $0,616 \%$ \\
\hline Span 80 & $2,384 \%$ & $2,384 \%$ & $2,384 \%$ \\
\hline Carbopol & $17,4 \%$ & $15,4 \%$ & $13,4 \%$ \\
\hline Gel Kitosan & $69,6 \%$ & $61,6 \%$ & $53,6 \%$ \\
\hline
\end{tabular}

\section{Uji Efektivitas Penyembuhan Luka Bakar Pada Hewan Uji}

Uji efektivitas sediaan dilakukan terhadap hewan uji kelinci (Oryctolagus cuniculus). Sebelum menginduksi luka bakar, bulu disekitar punggung kelinci dicukur menggunakan pengcukur rambut dan kelinci sisprai dengan chlore ethil. Induksi luka bakar dengan menggunakan logam panas selama 5 detik. Pada kulit yang mengalami luka bakar dilakukan pengamatan secara visual yaitu mengalami derajat luka bakar I, II atau III. Sediaan emulgel dioleskan secara merata pada permukaan luka dengan interval pengolesan 2 kali sehari selama 21 hari.

\section{Penghitungan Diameter Luka Bakar}

Data yang diperoleh dari penelitian berupa diameter luka bakar $(\mathrm{cm})$ yang diukur dengan jangka sorong (Einbill). Diameter luka bakar yang diperoleh dihitung dengan menggunakan rumus: 
$\mathrm{d}_{\mathrm{x}}=\frac{\mathrm{d}_{\mathrm{x} 1}+\mathrm{d}_{\mathrm{x} 2}+\mathrm{d}_{\mathrm{x} 3}+\mathrm{d}_{\mathrm{x} 4}+\mathrm{d}_{\mathrm{xn}}(\mathrm{dst})}{\mathrm{x}}$

Keterangan :

$\mathrm{dx}$ : diameter pada hari ke $\mathrm{x}$

$\mathrm{x}$ : hari pengamatan

Cara mengukur diameter luka bakar dapat dilihat pada gambar berikut :

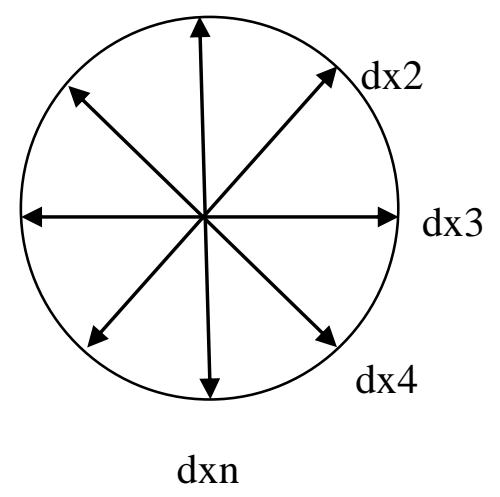

Gambar 1. Cara pengukuran diameter luka bakar

Kemudian hitung presentasi penyembuhan luka bakar dengan rumus berikut :

Keterangan :

$$
\mathrm{P} \%=\frac{d o-d x}{d o} \times 100 \%
$$

$\mathrm{P} \%:$ Persentase penyembuhan luka bakar

Do:Diameter luka bakar pada hari pertama

Dx:Diameter luka bakar pada hari pengamatan

\section{Analisis Data}

Analisis data dengan menggunakan statistik yaitu untuk mengetahui normalitas nilai sig $>0,05$ yang menunjukkan bahwa data terdistribusi normal. Homogenitas nilai sig > 0,05 menunjukkan bahwa data mempunyai homogenitas sama. Uji one way ANOVA nilai sig $<0,05$ menunjukkan bahwa data mempunyai tingkat kepercayaan 95\%. Uji post hoc untuk mengetahui perbandingan antar perlakuan.

\section{HASIL DAN PEMBAHASAN}

Penapisan Fitokimia Ekstrak Daun Sirih Merah (Pipper crocatum Ruiz \& Pav) dan Ekstrak Daun Binahong (Anredera cordifolia (Ten.) Steenis)

Penapisan fitokimia bertujuan untuk mengetahui kandungan senyawa sekunder dalam ekstrak daun sirih merah. Berikut adalah tabel hasil uji penapisan penapisan fitokimia ekstrak daun sirih merah:

Tabel 3. Hasil Penapisan Fitokimia Ekstrak Daun Sirih Merah

\begin{tabular}{|c|c|c|c|}
\hline $\begin{array}{c}\text { Golongan } \\
\text { senyawa }\end{array}$ & Reagen & Hasil & Keterangan \\
\hline Uji alkaloid & $\begin{array}{l}\mathrm{HCl}, \\
\text { Dragendroff }\end{array}$ & $(+)$ & $\begin{array}{l}\text { Endapan } \\
\text { jingga } \\
\text { coklat }\end{array}$ \\
\hline $\begin{array}{l}\text { Uji } \\
\text { flavonoid }\end{array}$ & $\begin{array}{l}\mathrm{HCl} \text { pekat, } \\
\text { serbuk } \mathrm{Mg} \text {, } \\
\text { amil alkohol }\end{array}$ & $(+)$ & $\begin{array}{l}\text { Warna } \\
\text { kuning }\end{array}$ \\
\hline Uji tanin & $\begin{array}{l}\text { Air panas, } \\
\text { emulgelatin }\end{array}$ & $(+)$ & $\begin{array}{l}\text { Terdapat } \\
\text { endapan } \\
\text { warna violet }\end{array}$ \\
\hline Uji saponin & $\begin{array}{l}\text { Air panas, } \\
\mathrm{HCl}\end{array}$ & $(+)$ & $\begin{array}{l}\text { Terdapat } \\
\text { busa yang } \\
\text { bertahan } \pm 5 \\
\text { menit pada } \\
\text { lapisan atas }\end{array}$ \\
\hline
\end{tabular}

Berdasarkan hasil penelitian tabel 1 ekstrak daun sirih merah positif mengandung alkaloid karena terbentuk endapan jingga coklat setelah direaksikan dengan $\mathrm{HCl}$ dan dragendroff. Alkaloid dalam sirih merah berfungsi sebagai antibakteri sehingga dapat mempercepat proses penyembuhan luka bakar pada hewan uji. Senyawa alkaloid merupakan 
golongan senyawa basa nitrogen yang kebanyakan heterosiklik. Senyawa alkaloid berfungsi sebagai antibakteri karena senyawa alkaloid mempunyai gugus basa yang mengandung nitrogen yang merusak inti sel bakteri sehingga bakteri menjadi lisis. Dengan demikian bakteri akan menjadi inaktif.

Ekstrak daun sirih merah positif mengandung flavonoid karena terjadi perubahan warna kuning setelah direaksikan dengan $\mathrm{HCl}$ pekat, serbuk $\mathrm{Mg}$ dan amil alkohol. Kandungan flavonoid dalam sirih merah berfungsi sebagai antiinflamasi dan antibakteri, sehingga mampu mengurangi nyeri, panas, bengkak, peradangan pada luka bakar. Flavonoid berfungsi sebagai antiinflamasi, antibakteri dengan cara membentuk senyawa komplek terhadap protein ektraseluler yang menganggu integritas membran sel bakteri.

Ekstrak daun sirih merah positif mengandung tanin karena terdapat endapan putih setelah direaksikan dengan air panas dan emulgelatin. Tanin dalam sirih merah berfungsi untuk menghambat pertumbuhan dinding sel bakteri. Tannin merupakan golongan senyawa fenolik sehingga tannin dapat bereaksi dengan protein membentuk kopolimer. Aktivitas antimikroba tannin yaitu berkaitan dengan kemampuannya dalam menginaktivasi adhesi, enzim-enzim, transpor protein pada mikroba serta dapat berikatan dengan polisakarida dan merusak membran sel.

Ekstrak daun sirih merah positif mengandung saponin karena terdapat busa pada lapisan atas setelah direaksikan dengan air panas dan $\mathrm{HCl}$. Saponin dalam sirih merah berfungsi untuk meregenari jaringan yang berperan dalam proses penyembuhan luka bakar. Saponin berfungsi sebagai antiseptik dan meregenerasi sel dengan cara pembentuk kolagen protein struktural yang berperan dalam proses penyembuhan luka.

Tabel 4. Penapisan Fitokimia Ekstrak Daun Binahong

\begin{tabular}{|c|c|c|c|c|}
\hline $\mathrm{NO}$ & $\begin{array}{c}\text { Golongan } \\
\text { senyawa }\end{array}$ & Reagen & Hasil & $\begin{array}{l}\text { Keterang } \\
\text { an }\end{array}$ \\
\hline 1. & $\begin{array}{c}\text { Uji } \\
\text { saponin }\end{array}$ & $\begin{array}{c}\text { air } \\
\text { panas+ } \\
\mathrm{HCl}\end{array}$ & + & $\begin{array}{c}\text { Terdapat } \\
\text { busa } \\
\text { yang } \\
\text { bertahan } \\
\pm 5 \text { menit } \\
\text { pada } \\
\text { lapisan } \\
\text { atas }\end{array}$ \\
\hline 2. & $\begin{array}{c}\text { Uji } \\
\text { polifenol }\end{array}$ & $\mathrm{FeCl} 3$ & + & $\begin{array}{c}\text { Larutan } \\
\text { berwarna } \\
\text { hijau } \\
\text { kehitama } \\
\text { n }\end{array}$ \\
\hline 3. & $\begin{array}{c}\text { Uji } \\
\text { flavonoid }\end{array}$ & $\begin{array}{c}\mathrm{HCl} \\
\text { pekat+ } \\
\text { serbuk } \\
\text { Mg+ amil } \\
\text { alkohol }\end{array}$ & + & $\begin{array}{c}\text { Warna } \\
\text { jingga / } \\
\text { merah }\end{array}$ \\
\hline 4. & $\begin{array}{c}\text { Uji } \\
\text { alkaloid }\end{array}$ & $\begin{array}{c}\mathrm{HCl}+ \\
\text { Dragendr } \\
\text { off }\end{array}$ & + & $\begin{array}{c}\text { Endapan } \\
\text { coklat } \\
\text { muda }\end{array}$ \\
\hline
\end{tabular}

Keterangan : (+) memberikan hasil positif

negatif

(-) memberikan hasil

Hasil penapisan fitokimia ekstrak daun binahong positif mengandung senyawa saponin. Senyawa saponin berperan sebagai antibakteri ${ }^{5}$ dengan cara menurunkan tegangan permukaan dinding sel, maka pada saat tegangan permukaan terganggu zat antibakteri akan masuk dengan mudah kedalam sel dan akan mengganggu metabolisme hingga akhirnya terjadilah kematian bakteri. Hasil penapisan fitokimia ekstrak daun binahong pada uji 
polifenol dengan menggunakan reagen $\mathrm{FeCl} 3$ memberikan hasil yang positif. ${ }^{6}$ pada penelitiannya menyatakan bahwa polifenol memiliki peran sebagai antibakteri.

Mekanisme polifenol sebagai agen antibakteri berperan sebagai toksin dalam protoplasma, merusak dan menembus dinding sel serta mengendapkan protein sel bakteri. Senyawa fenolik bermolekul besar mampu menginaktifkan enzim essensial di dalam sel bakteri meskipun dalam konsentrasi yang sangat rendah. Polifenol dapat menyebabkan kerusakan pada sel bakteri, denaturasi protein, menginaktifkan enzim, dan menyebabkan kebocoran sel.

Hasil penapisan fitokimia ekstrak daun binahong pada uji flavanoid dengan menggunakan reagen $\mathrm{HCl}$ pekat, serbuk $\mathrm{Mg}$ dan amil alkohol memberikan hasil yang positif. ${ }^{7}$ mengatakan bahwa senyawa flavonoid bekerja sebagai antibakteri dengan beberapa mekanisme aksi, diantaranya yaitu menghambat sintesis asam nukleat, menghambat fungsi membran sitoplasma dan menghambat metabolisme energi dari bakteri.

Mekanisme flavonoid sebagai antiinflamasi dapat melalui beberapa jalur menurut Ryansyah et al (2015) yaitu dengan penghambatan aktivitas enzim siklooksigenase (COX) dan lipooksigenase, penghambatan akumulasi leukosit, penghambatan degranulasi neutrofil, penghambatan pelepasan histamin.

Hasil penapisan fitokimia ekstrak daun binahong positif mengandung senyawa Alkaloid dengan menggunakan reagen $\mathrm{HCl}$ dan Dragendroff. Rosidah et al (2014) dalam penelitannya mengatakan bahwa senyawa alkaloid memiliki kemampuan sebagai antibakteri. Alkaloid mempunyai mekanisme penghambatan dengan cara berikatan dengan DNA. Hal ini diduga karena alkaloid memiliki gugus basa yang mengandung nitrogen. Gugus basa ini akan bereaksi dengan senyawa asam yang ada pada bakteri seperti DNA yang merupakan penyusun utama inti sel. Dengan terganggunya DNA maka sintesis protein dan asam nukleat dalam sel akan terganggu. Hal ini mengakibatkan metabolisme sel terganggu sehingga pertumbuhan bakteri terhambat atau mengalami kematian.

\section{Persentase Penyembuhan Luka Bakar Sediaan Emulgel Kitosan- Ekstrak Daun Sirih Merah (Pipper crocatum Ruiz \& Pav)}

Penyembuhan luka bakar dilihat dari berkurangnya diameter luka bakar. Pengukuran diameter dilakukan setiap hari dengan cara mencari dx. Hasil persentase penyembuhan luka bakar diperoleh dari diameter luka awal dikurangi diameter dihari ke-x kemudian dibagi diameter awal kemudian dikali 100\%. Hasil pengukuran diameter luka bakar dapat dilihat pada tabel

Tabel 5 Hasil persentase penyembuhan luka bakar terhadap hewan uji

\begin{tabular}{lcccccc}
\hline & & $\begin{array}{c}\text { DX } \\
1\end{array}$ & $\begin{array}{c}\text { DX } \\
21\end{array}$ & PX & $\begin{array}{c}\text { Rata- } \\
\text { rata } \\
(\%)\end{array}$ & $\begin{array}{c}\text { Mean } \pm \\
\text { SD }\end{array}$ \\
\hline Kontrol & H1 & 20, & 5,6 & 72, & & \\
Positif & & 13 & 3 & 03 & & \\
& H2 & 21, & 1,5 & 92, & 78,24 & $78,24 \pm$ \\
& & 7 & & 07 & & $12,00^{\mathrm{b}}$ \\
& H3 & 30, & 14, & 70, & & \\
\hline Kontrol & H1 & 23, & 7,1 & 48, & & $42,36 \pm$ \\
Negatif & & 5 & & 51 & 42,36 & $6,44^{\mathrm{a}}$ \\
& H2 & 25, & 9,5 & 42, & & \\
\hline
\end{tabular}




\begin{tabular}{ccccccc}
\hline & & 4 & & 91 & & \\
& H3 & 25, & 11, & 35, & & \\
& & 5 & 5 & 67 & & \\
\hline Formul & H1 & 39, & 7,6 & 73, & & \\
asi 1 & & 25 & 8 & 02 & & \\
$(3 \%)$ & & & & & & 67, \\
& H2 & 27 & 12, & 61, & 67,47 & 5,58 \\
& & & 3 & 85 & & \\
& H3 & 28, & 9,2 & 67, & & \\
\hline Formul & H1 & 20, & 4,9 & 71, & & \\
asi 2 & & 9 & 5 & 53 & & \\
$(6 \%)$ & & & & & & \\
& H2 & 27 & 9 & 70, & 77,99 & 12, \\
& & & & 37 & & \\
& H3 & 25, & 1,9 & 92, & & \\
& & 5 & 25 & 06 & & \\
\hline
\end{tabular}

Keterangan: (a) berbeda bermakna, (b) tidak berbeda makna

Berdasarkan diagram menunjukkan adanya pengurangan diameter luka bakar. Persentase penyembuhan luka bakar pada kontrol negatif 42,36\%, hasil ini menujukkan bahwa kontrol negatif kurang efektif. Formulasi 1 (3\%) mempunyai nilai $67,47 \%$, hasil ini menunjukkan bahwa formulasi 1 mempunyai efek yang lebih efektif daripada kontrol negatif. Formulasi 2 (6\%) mempunyai nilai $77,99 \%$, hasil ini menunjukkan bahwa formulasi 2 lebih efektif dari formulasi 1. Kontrol positif mempunyai nilai paling tinggi yaitu $78,24 \%$, hasil ini menunjukkan bahwa kontrol posif mempunyai efek paling efektif. Dari semua sediaan kontrol positif, kontrol negatif, formulasi 1 , formulasi 2 memiliki efek terhadap penyembuhan luka bakar. Semakin tinggi konsentrasi ekstrak daun sirih merah maka semakin tinggi nilai persentase penyembuhan luka bakar tetapi untuk penyembuhannya kontrol positif memiliki persentase penyembuhan luka lebih tinggi dibandingkan dengan formula yang mengandung ekstrak daun sirih merah.
Persentase Penyembuhan Luka Bakar Sediaan Emulgel KitosanEkstrak Daun Binahong (Anredera cordifolia (Ten.) Steenis)

Persentase Penurunan Diameter Luka 5,58 Bakar dari hari ke-0 sampai dengan hari ke lima mengalami peningkatan luas diameter rata-rata dari semua ketinci percobaan karena pada ke-0 sampai dengan hari ke-5 mengalami $77,99 \pm$ fase inflamasi dan menurut ${ }^{8}$ pada fase $12,20^{\text {tu }}$ luka mengalami tanda-tanda dari proses inflamasi antara lain adalah rubor (kemerahan), kalor (panas), Iumor (pembengkakan), dolor (nyeri), dan function laesa (perubahan fungsi).

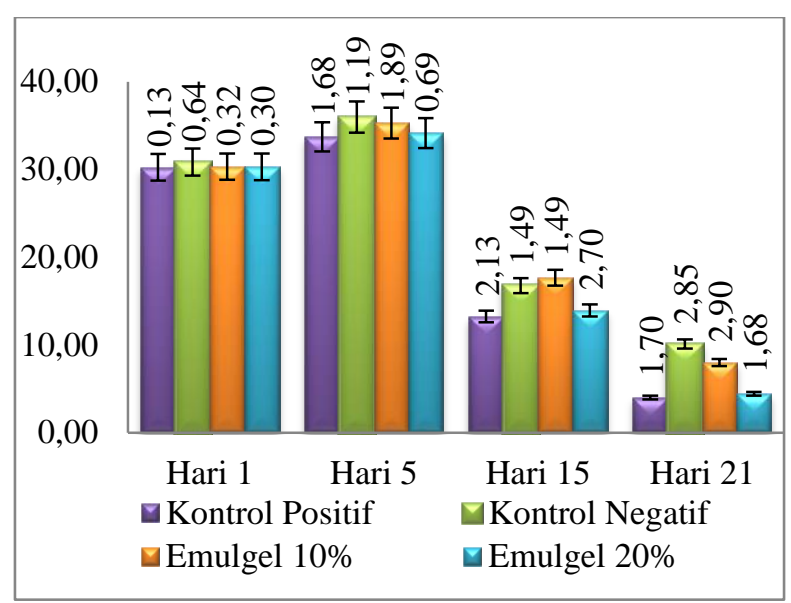

Gambar 1 Diagram Persen Penurunan Diameter Luka Bakar

Tabel 5 Data Persentase Penurunan Diameter Luka Bakar

\begin{tabular}{cccc}
\hline Perlakuan & $\begin{array}{c}\text { Hari } \\
\text { ke-1 } \pm \\
\end{array}$ & $\begin{array}{c}\text { Hari ke- } \\
21 \pm \\
\text { SD }\end{array}$ & $\begin{array}{c}\text { P\% } \pm \\
\text { SD }\end{array}$ \\
\hline Kontrol & 30,84 & 10,10 & 67,32 \\
negatif & $\pm 0,64$ & $\pm 2,85$ & $\pm 8,89$ \\
\hline Emulgel & 30,32 & $7,99 \pm$ & 73,68 \\
$10 \%$ & $\pm 0,32$ & 2,90 & $\pm 9,39$ \\
\hline Emulgel & 30,30 & $4,41 \pm$ & 85,46 \\
$20 \%$ & $\pm 0,30$ & 1,68 & $\pm 5,51$ \\
\hline Kontrol & 30,24 & $3,99 \pm$ & 86,81 \\
positif & $\pm 0,13$ & 1,70 & $\pm 5,65$ \\
\hline Ketangan
\end{tabular}

Keterangan :

P\% : Rata-rata Persentase Penurunan diameter Luka dari hari ke 1-21 
Rata-rata persentase penurunan diameter luka bakar untuk kontrol positif yaitu $86,81 \%$. kontrol negatif rata-rata persentase penurunan diameter luka bakar yaitu $67,32 \%$. ratarata persentase penurunan diameter luka bakar untuk emulgel $10 \%$ yaitu $73,68 \%$ dan rata-rata persentase penurunan diameter luka bakar untuk emulgel $20 \%$ yaitu $85,46 \%$. Data diatas dapat disimpulkan bahwa formulasi yang lebih baik antara emulgel ekstrak daun binahong $10 \%$ dan emulgel ekstrak daun binahong 20\% adalah emulgel ekstrak daun binahong 20\% ditunjukkan dengan nilai persentase penurunan diameter luka bakar yang lebih besar dibandingkan emulgel ekstrak daun binahong 10\%. Emulgel ekstrak daun binahong 20\% memiliki potensi yang sama atau hampir sama dengan kontrol positif terhadap penyembuhan luka bakar.

Untuk mengetahui adanya pengaruh perbedaan konsentrasi ekstrak daun binahong terhadap pengecilan diameter luka bakar maka di lakukan uji normalitas data dan homogenitas varian, selanjutnya di lakukan uji satatistik parametric one way ANOVA. Uji one way ANOVA dipilih karena hanya ada satu variabel independen yang akan diteliti, yaitu persentase penyembuhan luka bakar.

Uji Anova Sediaan Emulgel KitosanEkstrak Daun Sirih Merah (Pipper crocatum Ruiz \& Pav) dan Emulgel Kitosan-Ekstrak Daun Binahong (Anredera cordifolia (Ten.) Steenis)

Tabel 6 Hasil Uji One-Way ANOVA Sediaan Emulgel KitosanEkstrak Daun Binahong

\begin{tabular}{cccccc}
\hline & $\begin{array}{c}\text { Sum of } \\
\text { Square } \\
\text { s }\end{array}$ & $\begin{array}{c}\mathrm{d} \\
\mathrm{f}\end{array}$ & $\begin{array}{c}\text { Mean } \\
\text { Squar }\end{array}$ & $\mathrm{F}$ & $\mathrm{Sig}$ \\
e & & \\
Betwe & 796.63 & 3 & 265.5 & 4.63 & .03 \\
en & 3 & & 44 & 1 & 7 \\
Group & & & & & \\
s & & & & & \\
Within & 458.75 & 8 & 57.34 & & \\
Group & 9 & & 5 & & \\
s & & & & & \\
Total & 1255.3 & 1 & & & \\
& 92 & 1 & & & \\
\hline
\end{tabular}

Didapatkan hasil $p$ Value sebesar $0,037 \quad(p<0,05)$, menandakan bahwa diantara semua kelompok penelitian memiliki perbedaan yang bermakna.

Uji Perbandingan Sediaan Emulgel Kitosan-Ekstrak Daun Sirih Merah dan Emulgel Kitosan-Ekstrak Daun Binahong (Anredera cordifolia (Ten.) Steenis) dengan menggunakan Analisis Post Hoc

Analisis Post Hoc merupakan kelanjutan Analisis ANOVA) jika perbedaan bermakna. Untuk melanjutkan perbedaan bermakna perlu dilakukan uji post hoc, hasil menunjukkan bahwa ada perbedaan bermakna. Interpretasi data pada tabel LSD menyatakan adanya perbedaan yang signifikan.

\section{DAFTAR PUSTAKA}

WHO. 2005. National Policy on Traditional Medicine and Regulation of Herbal Medicines, Report of a WHO global survey, Geneva.

Inriani, M. M. R., dkk. (2012). Formulasi dan uji krim ekstrak umbi singkong (Manihot esculenta) terhadap luka bakar pada kelinci (Oryctolagus 
cuniculus), FMIPA-UNSRAT, Manado.

Rismana, E. (2010). Pengembangan Formulasi Sediaan Topikal Wound Healing Menggunakan Bahan Aktif Kitosan dan Ekstrak Pegagan, Pusat Teknologi Farmasi Dan Medika - Deputi Bidang TAB - BPPT, Jakarta.Hal 7.

Indri, W.W., Anthoni, M.S.S.,\& Setyorini, W. (2008). Sirih Merah, Balai Kajian Teknologi Pertanian Yogyakarta: Yogyakarta. Hal 1-4.

Abdassah, M., Sumiwi, S.A., Hendrayana, J. (2009). Formulasi Ekstrak Daun Sukun (Artocarpus Altilis (Parkins.) Fosberg) Dengan Basis Gel Sebagai Antiinflamasi. Jurnal Farmasi Indonesia, 4 (4), 199 209.

Soerya Dewi. (2013). Aktivitas Antibakteri Minyak Atsiri Daun Sirih Merah (Piper crocatum ruiz \& pav.), Jurusan Kimia, Fakultas Matematika dan Ilmu Pengetahuan Alam, Universtas SebelasMaret, Kentingan Surakarta. 7.

Paju, N., Yamlean, P.V.Y., dan Kojong, N. 2013. Uji Efektivitas Salep Ekstrak Daun Binahong (Anredera cordifolia (Ten.) Steenis) Pada Kelinci (Oryctolagus cuniculus) yang Terinfeksi Bakteri Staphylococcus aureus. Jurnal Ilmiah Farmasi, Vol. 2 (1): 5161.

Prakash, Gupta S. 2005. Therapeutic uses of Ocimum Sanctum Linn (Tulsi) with a note on eugenol and its pharmacological action. Indian J Physiol Pharmacol; 49 (2): 126.
Rochani, N. 2007. Uji Aktivitas Antijamur Ekstrak Daun Binahong (Anredera cordifolia (Tenore) Steenis) Terhadap Candida albicans Serta Skrining Fitokimianya. Skripsi. Surabaya : Fakultas Farmasi UMS Surakarta.

Manoi, F. 2009. Binahong (Anredera cordifolia) (Ten) Steenis Sebagai Obat. Jurnal Warta Penelitian Dan Pengembangan Tanaman Industri. Vol 15 No 1:3.

Shabella, R. 2012. Terapi Daun Binahong. Cetakan Ke-1. Klaten: Cable Book.

Suseno. 2013. Kandungan binahong. http: www.jurnal.stkipgarut.ac.id. Diakses tanggal 19 September 2016.

Prakash, A. 2001. Antioxidant Activity. Medallion Laboratories : AnalithycalProgres, Vol. 19 No. 2.1 - 4.

Kozier, B., Erb, G., Blais, K, dan Wilkinson, J.M. 1995. Fundammentals of Nursing: Concepts, Process, and Practice. California: AddisonWeasley.

Robert, F. D., dan Evans, M. C. 2004. Wound healing: An Overview Of Acute, Fibrotic and Delayed Healing. Frontiers in Bioscience, No. 9, 283-289.

Syarfati K, Eriani, Damhoeri A. 2011. The potential of jarak cina (Jatrophamultifida L.) secretion in healing newwounded mice. Jurnal Natural; 11(1):16.

Rembulan, V., 2015. Potency Of Honey In Treatment Of Burn Wounds. Jurnal Majority, Vol. 04, No. 01. 
Rismana, E., Idah, R., Prasetyawan, Y., Olivia, B., Erna, Y., 2013. Efektivitas Khasiat Pengobatan Luka Bakar Sediaan Gel Mengandung Fraksi Ekstrak Pegagan Berdasarkan Analisis Hidroksiprolin Dan Histopatologi Pada Kulit Kelinci. Pusat Teknologi Farmasi dan Medika, Badan Pengkajian dan Penerapan Teknologi. Bul. Penelit. Kesehat, Vol. 41, No. 1, 2013: $45-60$.

Zulfa, E., Tegar, B.P., Mimik, M., 2015. Formulasi Salep Ekstrak Etanolik Daun Binahong (Anrederacordifolia (Ten.) Steenis) Dengan Variasi Basis Salep. Fakultas Farmasi Universitas Wahid Hasyim Semarang dan Fakultas Farmasi Universitas GadjahMada Yogyakarta.

Isrofah, S., Moh. Afandi., 2015. Efektifitas Salep Ekstrak Daun Binahong (Anredera Cordifolia (Ten) Steenis) Terhadap Proses Penyembuhan Luka Bakar Derajat 2 Termal pada Tikus Putih (Rattus Novergicus). Muhammadiyah Journal of Nursing.

Perwita, F.A.. 2011. “ Teknologi Ekstraksi Daun Ungu (Graptophyllum pictum) Dalam Etanol 70\% Dengan Metode Perkolasi"Skripsi.

Surakarta:Fakultas Pertanian, Universitas Sebelas Maret.

Rosidah, A.N., Pujiana, E.L., Pudji, A., 2014. Daya Antibakteri Ekstrak Daun Kendali (Hippobroma Longiflora [L] G. Don) Terhadap Pertumbuhan Streptococcus Mutans. Artikel Ilmiah Hasil Penelitian Mahasiswa. Jurnal Pustaka
Kesehatan, Vol. (No.), Bulan, Tahun.

Manik, D.F., Triana, H., Hady, A., 2014. Analisis Korelasi Antara Kadar Flavonoid Dengan Aktivitas Antibakteri Ekstrak Etanol Dan Fraksi-Fraksi Daun Kersen (Muntingia Calabura L.) Terhadap Staphylococcus Aureus. Khazanah, Vol. 6 No.2.

Wiranto, E., Muhamad, A.W., Puji, A., 2016. Aktivitas Antiinflamasi Secara In-Vitro Ekstrak Teripang Butoh Keling (Holothuria Leucospilota Brandt) Dari Pulau Lemukutan. Jkk, Tahun 2016, Volume 5(1), Halaman 52-57. 